\title{
Immunotherapeutic effect of the lactobacillus vaccine, Solco Trichovac, in trichomoniasis is not mediated by antibodies cross reacting with Trichomonas vaginalis
}

\author{
A GOMBOSOVÁ, P DEMES, AND M VALENT \\ From the Institute of Parasitology, Comenius University, Bratislava, Czechoslovakia.
}

SUMMARY According to the producers of the lactobacillus vaccine, SolcoTrichovac, its therapeutic effect in trichomoniasis is achieved by antibodies that are induced by the vaccination and cross react with Trichomonas vaginalis. Common antigens of Lactobacillus acidophilus from SolcoTrichovac vaccine and $T$ vaginalis were therefore sought by three different seroreactions. Immune serum against $L$ acidophilus obtained by vaccinating two healthy human volunteers and two rabbits with the original SolcoTrichovac vaccine, as well as hyperimmune rabbit antiserum to $T$ vaginalis, were tested with each of the two micro-organisms. No evidence of antigenic similarity between $L$ acidophilus and $T$ vaginalis was obtained with either serum in any of the three serological tests. A non-specific immunostimulatory effect therefore seems to be a more probable explanation of the mode of action of SolcoTrichovac vaccine.

\section{Introduction}

At the end of the 1970s a lactobacillus vaccine, SolcoTrichovac, was introduced by the Swiss company, Solco (Basel), as a new treatment of urogenital trichomoniasis in man. The systemic vaccine, which consists of eight inactivated aberrant strains of Lactobacillus acidophilus isolated from patients infected with Trichomonas vaginalis, should represent an alternative to nitroimidazole chemotherapy. According to various authors, the efficacy of SolcoTrichovac immunotherapy is $90-100 \% .^{1}$

Hungarian workers first reported attempts to control urogenital trichomoniasis by immunisation with inactivated lactobacilli, which were isolated either from patients with trichomoniasis or from healthy virgins. ${ }^{2}$ As with streptococcal ${ }^{3}$ or trichomonal vaccines, ${ }^{24-6}$ Solco Trichovac was more effective at resolving clinical signs than in reducing the number of parasites in the vagina.

The precise mode of action of the bacterial vaccines against trichomoniasis is poorly understood. The hypothesis proposed by the makers of SolcoTrichovac is that the vaccine induces cross reacting antibodies against abnormal lactobacilli and $T$ vaginalis without

\footnotetext{
Address for reprints: $\mathrm{Dr} P$ Demes, Institute of Parasitology, Comenius University, Palisády 40, 81106 Bratislava, Czechoslovakia Accepted for publication 21 July 1985
}

adversely affecting the growth of normal lactobacilli in the vagina. Clinical improvement as well as the elimination of $T$ vaginalis should therefore occur in the course of vaccination.?

The concept of antigenic similarity of two such unrelated and serologically variable groups of organisms as lactobacilli and trichomonads is rather surprising. The aim of the present study was therefore to assess the serological cross reactivity between lactobacilli from SolcoTrichovac vaccine and $T$ vaginalis.

Patients, materials, and methods

ISOLATION AND CULTIVATION OF $T$ VAGINALIS

Material for the isolation of $T$ vaginalis was obtained from the posterior fornix of the vagina of unselected patients attending this institute. The parasites were grown in Diamond's trypticase, yeast extract, and maltose (TYM) medium ${ }^{8}$ supplemented with $10 \%$ heat inactivated beef serum at $37^{\circ} \mathrm{C}$. For axenisation, antibiotics (1000 IU penicilin G and $1 \mathrm{mg}$ streptomycin sulphate $/ \mathrm{ml}$ ) were added to the medium in three subsequent subcultures. Axenic cultures were maintained by serial passages at two day intervals in the same medium without antibiotics. For the preparation of trichomonal antigen, flagellates were transferred three times in Diamond's TYM medium without agar. We used 24 to 48 hour old cultures derived from the last transfer. 
PREPARATION OF ANTISERA

Two human volunteers (a woman and a man, both aged 29) with no history of trichomoniasis were immunised with SolcoTrichovac vaccine according to the schedule recommended by the producers. The vaccine was administered by intramuscular injection in three separate doses at intervals two weeks apart. Each injection consisted of $0.5 \mathrm{ml}$ vaccine containing at least $7 \times 10^{9}$ inactivated micro-organisms of eight strains of $L$ acidophilus. Control serum samples were collected before immunisation, and immune serum samples two weeks after the third dose.

Rabbit antiserum to lactobacillus was obtained by immunising two silver rabbits (about $3.5 \mathrm{~kg}$ in weight) with SolcoTrichovac vaccine given intravenously in three doses at weekly intervals. The immune serum was obtained by cardiac puncture one week after the final dose. Pooled preimmune serum served as a control. Antitrichomonal hyperimmune rabbit serum was prepared as described previously. ${ }^{9}$ Briefly, a male silver rabbit was immunised by increasing numbers of live $T$ vaginalis strain $\mathrm{K}-1$ in five $1 \mathrm{ml}$ doses (containing $1 \times 10^{7}, 1 \cdot 5 \times 10^{7}, 2 \times 10^{7}, 2 \cdot 5 \times 10^{7}$, or $2.5 \times 10^{7}$ cells ) at weekly intervals. The rabbit was bled two weeks after the final injection. All serum samples were inactivated at $56^{\circ} \mathrm{C}$ for 30 minutes and stored at $-20^{\circ} \mathrm{C}$.

\section{PREPARATION OF ANTIGENS}

$T$ vaginalis antigen for serological testing was prepared from equal concentrations of six different strains cultivated in vitro for a maximum of two weeks. Twenty four to 48 hour old cultures were centrifuged at $800 \times g$ for 10 minutes and washed three times in phosphate buffered saline (PBS), pH 7·2. Washed organisms were used as living antigen in the agglutination tests. For the indirect immunofluorescence assay a small drop of trichomonal suspension was spread on each of the ten circles marked on a Teflon covered slide. The slides were air dried, fixed in acetone for 10 minutes, and either used immediately or stored at $-20^{\circ} \mathrm{C}$ until used. Lactobacillus antigen for indirect immunofluorescence assay was prepared from cells of the SolcoTrichovac original vaccine diluted 1:5 with PBS by the same procedure as was used for $T$ vaginalis antigen.

$T$ vaginalis soluble antigen for indirect haemagglutination was prepared by disrupting the washed cells by repeatedly (10 times) freezing them in liquid nitrogen and thawing at $40^{\circ} \mathrm{C}$. The homogenate was centrifuged at $13000 \times g$ for 20 minutes and the supernatant was stored at $-20^{\circ} \mathrm{C}$. The protein concentration of antigen estimated by Lowry's method $^{10}$ was $50 \mathrm{mg} / \mathrm{l}$.

\section{SEROLOGICAL REACTIONS}

\section{Agglutination}

We used a micromodification of the assay described by Kott and Adler. ${ }^{11}$ Serial twofold dilutions of inactivated serum in $0.9 \%$ sodium chloride were set up in $0.1 \mathrm{ml}$ volumes in plastic microtitration plates with $\mathrm{U}$ bottoms (Koh-I-Noor, Czechoslovakia). Equal volumes of a suspension of living washed trichomonads (at a concentration of $3 \times 10^{6} / \mathrm{ml}$ ) were added. The plates were briefly agitated and incubated for two hours at room temperature. Agglutination was examined macroscopically. A positive reaction was associated with a characteristic pattern, the agglutinated cells forming a homogeneous covering at the bottom of the well. A negative reaction was distinguished by a compact spot of sedimented organisms. In these tests and in indirect immunofluorescence assays titres were expressed as the serum dilutions at the end point.

\section{Indirect immunofluorescence assay}

We performed indirect immunofluorescence assays with both trichomonal and lactobacillus antigen by a modification of the method described previously for $T$ vaginalis. ${ }^{12}$ Briefly, one drop of an appropriate dilution of the tested serum was added to each antigen spot. The slides were incubated at $20^{\circ} \mathrm{C}$ for 30 minutes in a moist chamber and washed in tap water for 10 minutes, in PBS for 15 minutes, and in tap water again for 10 minutes. After being dried at room temperature, each spot was covered with one drop of fluorescein isothiocyanate conjugated swine anti human or anti rabbit immunoglobulin (USOL, Prague) diluted 1:6 and 1:4 respectively. The slides were incubated and washed as above, immersed in an aqueous solution of Evan's blue (diluted 1:50 000) for 15 minutes at room temperature, and washed as before. After being dried the slides were mounted in buffered glycerol (diluted 9:1 in PBS) and examined with a Zeiss Fluoval microscope. Positive reactions were associated with distinct fluorescence of the cell surface.

Control slides were prepared using tested serum samples without conjugate and using conjugate without tested serum.

\section{Indirect haemagglutination assay}

Fresh sheep erythrocytes were centrifuged at $800 \times g$ for 10 minutes and washed three times in PBS. A $2.5 \%$ suspension of erythrocytes was mixed with an equal volume of tannic acid (diluted 1:120 000 in PBS) and incubated in an ice bath for 15 minutes. After being centrifuged at $800 \times g$ for 10 minutes and washed repeatedly in PBS, the sediment was incubated with an equal volume of soluble trichomonal antigen for 15 minutes at $37^{\circ} \mathrm{C}$. Sensitised erythrocytes were washed in PBS and diluted to a $2.5 \%$ suspension in PBS.

We used a modification of the tube assay described 
by Kott and Adler ${ }^{11}$ as follows: aliquots of tested serum at dilutions of 1:20 to 1:1280 in PBS were dispensed to each tube. After $0.05 \mathrm{ml}$ sensitised erythrocytes had been added, the tubes were incubated for 24 hours at $20^{\circ} \mathrm{C}$. Controls of sensitised erythrocytes and of individual serum samples with non-sensitised erythrocytes were included.

As the specific humoral responses in two human volunteers, as well as the responses of the two rabbits vaccinated with SolcoTrichovac, were similar, parallel serum samples from the same species were pooled before use in further experiments.

\section{Results}

The antigenic relation of $T$ vaginalis and $L$ acidophilus from Solco Trichovac vaccine was investigated by serological cross reactions of human and rabbit antiserum against each of the two micro-organisms.

Table I shows the specific antibody response against $L$ acidophilus generated in the course of vaccination with Solco Trichovac in the serum of healthy people and rabbits. Antibodies were not detected in rabbit hyperimmune antiserum to $T$ vaginalis by

TABLE I Antilactobacillus antibody titres by immunofluorescence assay of human and rabbit serum before and after vaccination with of SolcoTrichovac compared with those in rabbits immunised with Trichomonas vaginalis

\begin{tabular}{llll}
\hline & Titres & \\
\cline { 2 - 4 } Serum & Mean & Range & $\begin{array}{l}\text { No of } \\
\text { tests }\end{array}$ \\
\hline Human: & & & \\
$\quad$ Before vaccination & $1 / 8$ & $1 / 4-1 / 16$ & 4 \\
$\begin{array}{l}\text { After vaccination } \\
\text { Rabbit: }\end{array}$ & & & 4 \\
$\quad$ Before vaccination & & $1 / 16-1 / 64$ & 3 \\
$\quad$ After vaccination & $1 / 32$ & & 5 \\
$\quad \begin{array}{l}\text { Immunised with } \\
\text { T vaginalis }\end{array}$ & & & \\
\hline
\end{tabular}

immunoflourescence with $L$ acidophilus antigen, which indicated the absence of any antigenic similarity between the two micro-organisms.

The results of cross reacting tests of antisera against $L$ acidophilus with trichomonal antigen, summarised in Table II, confirmed the lack of common antigens in the two organisms. No appreciable increase in the titres of antibodies against $T$ vaginalis after vaccination with Solco Trichovac could be detected by indirect immunofluorscence or haemagglutination assays or by agglutination in either serum. When, however, $T$ vaginalis antigen was tested with rabbit antiserum to $T$ vaginalis, high titres of specific antibodies were obtained in all serological tests. The increase compared with preimmune serum was 170 fold by indirect immunofluorescence assay, 64-fold by indirect haemagglutination assay, and 17 -fold by agglutination.

\section{Discussion}

According to the manufacturers of the lactobacillus vaccine Solco Trichovac, its immunotherapeutic effect in trichomoniasis is accomplished by stimulation of the specific immune response in the serum and probably also in the cervical secretion of the host. The mode of action of the vaccine, as claimed by the producers, is the induction of antibodies against aberrant $L$ acidolphilus, which cross react with $T$ vaginalis but not with physiological Doederlein's bacillus. ${ }^{7314}$

An increase in specific antilactobacillus agglutinins has been reported during the course of vaccination, ${ }^{15}$ but few data supporting the presence of cross reacting antibodies have yet been presented. The only evidence of common antigens in $T$ vaginalis and $L$ acidophilus has been obtained by Stojković ${ }^{16}$ and Bonilla-Musoles et $a l^{17}$ using indirect immunofluorescence assays.

In our experiments we failed to show any antigenic relation between lactobacilli from SolcoTrichovac

TABLE II Antitrichomonal antibody titres in rabbit and human serum before and after vaccination with three doses of SolcoTrichovac compared with those in rabbits immunised with Triomonas vaginalis

\begin{tabular}{|c|c|c|c|c|c|c|c|c|c|}
\hline \multirow[b]{2}{*}{ Serum } & \multicolumn{3}{|c|}{ By immunofluorescence: } & \multicolumn{3}{|c|}{ By haemagglutination: } & \multicolumn{3}{|c|}{ By agglutination: } \\
\hline & Mean & Range & $\begin{array}{l}\text { No of } \\
\text { tests }\end{array}$ & Mean & Range & $\begin{array}{l}\text { No of } \\
\text { tests }\end{array}$ & Mean & Range & $\begin{array}{l}\text { No of } \\
\text { tests }\end{array}$ \\
\hline \multicolumn{10}{|l|}{ Human } \\
\hline Before vaccination & $1 / 7 \cdot 6$ & $0-1 / 16$ & 6 & $1 / 16$ & $0-1 / 40$ & 5 & $1 / 112$ & $1 / 40-1 / 160$ & 10 \\
\hline After vaccination & $1 / 6 \cdot 8$ & $0-1 / 16$ & 6 & $1 / 12$ & $0-1 / 40$ & 5 & $1 / 156$ & $1 / 40-1 / 320$ & 10 \\
\hline \multicolumn{10}{|l|}{ Rabbit: } \\
\hline Before vaccination & $1 / 1 \cdot 5$ & $1 / 1-1 / 2$ & 4 & $1 / 10$ & $0-1 / 20$ & 4 & $1 / 151$ & $1 / 80-1 / 160$ & 7 \\
\hline $\begin{array}{l}\text { After vaccination } \\
\text { Immunised with }\end{array}$ & $1 / 3 \cdot 2$ & $1 / 2-1 / 4$ & 4 & $1 / 12$ & $0-1 / 40$ & 4 & $1 / 111$ & $1 / 40-1 / 160$ & 9 \\
\hline$T$ vaginalis & $1 / 256$ & $1 / 64-1 / 512$ & 5 & $1 / 640$ & $1 / 320-1 / 128$ & 803 & $1 / 2560$ & $1 / 640-1 / 5120$ & 7 \\
\hline
\end{tabular}


and several strains of $T$ vaginalis. No increase of antitrichomonal antibodies due to the vaccination, performed according to the original schedule, could be detected by any test in either human or rabbit serum. Moreover, rabbit antiserum to $T$ vaginalis did not react with $L$ acidophilus antigen in the indirect immunofluorescence assay, which suggested the absence of any common antigen in $T$ vaginalis and $L$ acidophilus from SolcoTrichovac. The weak positivity of all preimmune serum samples to $T$ vaginalis was probably due to the presence of natural antibodies against $T$ vaginalis in normal serum, which have been reported by several authors. ${ }^{18-20}$

In our experiments we recorded only a slight increase in titre of specific antibodies against $L$ acidophilus in both human and rabbit serum after vaccination with SolcoTrichovac. This finding confirms the low immunogenicity of lactobacilli. ${ }^{21}$

As both $L$ acidophilus and $T$ vaginalis occur in numerous serotypes, ${ }^{21-23}$ similarity of the two organisms seems to be very unlikely. Moreover, Doederlein flora comprise several species of lactobacillus, with interspecific as well as intraspecific serological differences. ${ }^{24} 25$

Our results and the data discussed above do not support the claim of the manufacturers of SolcoTrichovac. Nevertheless, the clinical effect reported so far is remarkable. ${ }^{1}$ If it is confirmed, a different explanation for the mode of action of the vaccine will have to be sought by further investigations of the microbial interactions in the vagina as well as of the antigenic relations of the indiviual microorganisms.

We thank Drs H Tlaskalová and J Kulda for their critical and stimulating comments, Dr Kourlová for supervising the English, and Mrs M Červeñová for typing the manuscript.

\section{References}

1. Symposium on trichomoniasis. Basle, 20 October 1981. Gyñakol Rundsh 1983;23 suppl 2:1-88.

2. Uihelyi K, Philipp G, Plank G, Sagi T. A trichomonas syndroma. Magyar Nöorvosok Lapja 1973;36:433-42 (In Hungarian, English summary).

3. Hibbert GF, Falls FH. Further observations on the role of streptococcus in so-called Trichomonas vaginalis vaginitis. Am J Obstet Gynecol 1938;36:219-29.

4. Rodecurt M. Beiträge zum Trichomonasproblem nebst Bemerkungen über "unspezifischen" Fluor. Zeitschrift für Geburtshilfe und Gynäkologie 1934;107:217-42.
5. Aburel E, Zervos G, Rusu A, Titea V. Panå S Immunobiological and therapeutic investigations in vaginal trichomoniasis. Microbiologia Parazitologia Epidemiologia 1963;VIII:145-52 (Rumanian with English summary) and Rumanian Medical Revue 1963;7:13-9.

6. Korik LM, Ljubimova LK, Tovstolec KP. Immediate and remote results of treatment of trichomonosis in men with trichomonal vaccine. Vestn Dermatol Venerol 1968;42:80-4 (Russian with English summary).

7. Pavić R, Stojković L. Vaccination with SolcoTrichovac. Immunological aspects of a new approach for therapy and prophylaxis of trichomoniasis in women. Gynäkol Rundsch 1983;23 suppl 2:27-38.

8. Diamond LS. The establishment of various trichomonads of animals and man in axenic cultures. J. Parasitol 1957;43:488-90.

9. Quang LB, Demes P, Valent $\mathbf{M}$. Stúdium protilátkovej odpovede králikov imunizovaných Trichomonas vaginalis pomocou niekolkých séroreakcii. Bratisl Lek Listy 1984;82:82534 (Slovac with English summary).

10. Lowry $\mathrm{OH}$, Rossebrough NJ, Farr AL, Randall RJ. Protein measurement with the Folin phenol reagent. J Biol Chem 1951;193:265-75.

11. Kott M, Adler S. A serological study of Trichomonas sp parasitic in man. Trans $R$ Soc Trop Med Hyg 1961;55:333-44.

12. Kramár J, Kučera K. Immunofluorescence demonstration of antibodies in urogenital trichomoniasis. J Hyg Epidemiol Microbiol Immunol 1966;10:85-8.

13. Stojković L. SolcoTrichovac: mechanism of action. Basel: Solco. Registration documentation 1982.

14. Stojković L. Der Wirkungsmechanismus von SolcoTrichovac Internazionalen symposium über unspezifische vaginitis und trichomoniasis (in press).

15. Milovanović R, Grčić R, Stojković L. Serological study with SolcoTrichovac, a vaccine against Trichomonas vaginalis infection in women. Gynäkol Rundsch 1983;23:(suppl 2):39-45.

16. Stojković $\mathrm{L}$. New evidence elucidating the mechanism of action of gynatren/Solco-Trichovac. Gynäkol Rundsch 1984;24:(suppl 3):29-37.

17. Bonilla-Musoles F, Sanches-Pena JM, Pellicer A, Guevara F, Ziegler WJ. A vaccine against vaginal trichomoniasis in humans. A temporary solution of the problem? Revista Española de Obstetricia y Ginecologia 1983;42:777-89.

18. Reisenhofer U. Uber die Beeinflussung von Trichomonas vaginalis durch verschiedene Sera. Archiv fur Hygiene und Bakteriologie 1963;146:628-35.

19. Samuels $R$, Chun-Hoon $H$. Serological investigations of trichomonads. I. Comparison of "natural" and immune antibodies. J Protozool 1964;11:36-46.

20. Teras JK. On the existence of antibodies agglutinating, immobilizing and lysing Trichomonas vaginalis in the blood sera of healthy people and rabbits. Iss/edovania Mikrobiologiceskije 1961;43-53

21. Shimohashi H, Mutai M. Species antigens of Lactobacillus acidophilus. J Gen Microbiol 1977;103:337-44.

22. Efthymiou C, Hansen PA. An antigenic analysis of Lactobacillus acidophilus. J Infect Dis 1962;110:258-62.

23. Honigberg BM. Trichomonads of importance in human medicine. In: Kreier JP, ed. Parasitic protozoa. 2nd ed. New York: Academic Press, 1978:275-454.

24. Rogosa M. Lactobacillaceae. In: Buchanan RE, Gibbons NE eds. Bergey's manual of determinative bacteriology. Baltimore: Williams and Wilkins, 1974:576-93.

25. Lencner AA. Species composition of vaginal lactobacilli in the menopause. Učenve Zapiski Tartuskogo Gosudarstvennogo Universiteta 1969;249:453-66 (Russian with English summary). 